\title{
STUDIES OF THE CORTINARIUS SANIOSUS (FR.: FR.) FR. COMPLEX AND A NEW CLOSELY RELATED SPECIES, C. AUREOVELATUS (BASI- DIOMYCOTA, AGARICALES)
}

\author{
H. Lindström, E. Bendiksen, K. Bendiksen \& E. Larsson
}

Lindström, H., Bendiksen, E., Bendiksen, K. \& Larsson, E. 2008. Studies of the Cortinarius saniosus (Fr.: Fr.) Fr. complex and a new closely related species, C. aureovelatus (Basidiomycota, Agaricales). - Sommerfeltia 31: 139-159. ISBN 82-7420-045-4. ISSN 0800-6865.

The variation of the widely spread Cortinarius saniosus is described with respect to morphological, ecological and molecular characteristics. C. chrysomallus D. Lamoure and C. aureomarginatus P.D. Orton are regarded as synonymous with $C$. saniosus based on morphological and molecular data. A new closely related species $C$. aureovelatus Bendiksen, $\mathrm{K}$. Bendiksen \& H. Lindstr., growing in coniferous and mountain birch forests, is described. A taxonomical and nomenclatural treatment of the complex, based upon present knowledge, is proposed.

Keywords: Cortinarius, Fennoscandia, The Internal Transcribed Spacer region, taxonomy, Telamonia.

Håkan Lindström, Vikingav.71C, SE 85742 Sundsvall, Sweden, e-mail: hakan.lindstrom@delta. telenordia.se

Egil Bendiksen, Norwegian Institute for Nature Research, Gaustadalléen 21, NO-0349 Oslo, Norway, e-mail: egil.bendiksen@nina.no

Katriina Bendiksen, Department of Botany, Natural History Museum, University of Oslo, P.O. Box 1172 Blindern, NO-0318 Oslo, e-mail: katriina.bendiksen@nhm.uio.no

Ellen Larsson, Göteborg University, Dep of Biology, Box 461, SE 405 30, Göteborg, Sweden, e-mail: ellen.larsson@botany.gu.se

\section{INTRODUCTION}

Small species of Cortinarius subgenus Telamonia with golden yellow veil and coarsely ornamented and broadly ellipsoid spores are relatively common under several species of deciduous trees in Fennoscandia (e.g. Betula, Quercus, Tilia, Salix, Populus). These Telamonia species have usually been called C. saniosus (Fr.: Fr.) Fr. Lamoure (1977) described a closely related alpine taxon, C. chrysomallus, which she found under dwarf-willows both in the Alps and in the Scandinavian mountains. Cortinarius chrysomallus is characterized in particular by its violet tinges of the veil and stipe base. Orton (1984) described C. aureomarginatus from willow vegetation in the British lowlands. According to Orton this species has slightly longer and more amygdaliform spores than C. saniosus. 
In this study we aim at examining how the $C$. saniosus complex varies in morphology and in relation to different symbionts, from the nemoral to the alpine zones and over a wide geographic area. We have included in this study specimens named C. saniosus (in a broad sense) or C. chrysomallus and also C. aureomarginatus (type). In addition to the C. saniosus complex (in this strict sense) a similar and closely related taxon has been observed in Fennoscandia during the last decades. This species has distinctly narrower and less strongly verrucose spores, grows with coniferous trees $(P i-$ $n u s$, Picea) and in the mountain birch forest, and seems to have been overlooked or mixed with $C$. saniosus. The species is here described as C. aureovelatus.

In an effort to put morphological and ecological data into a broader context, and to provide a firmer basis for a new taxonomy, phylogenetic analysis based on nuclear ribosomal DNA sequence data has also been performed.

Our results raise the question of how strictly "alpine" our alpine species of fungi really are. This question is discussed.

\section{MATERIALS AND METHODS}

\section{Morphological methods}

About 100 collections of the taxa treated were examined. Examined collections include mainly Fennoscandian collections made by the authors, collections by M. Moser (IB), and specimens filed under $C$. saniosus in $\mathrm{O}$. A comparative analysis of the macro and micro morphological characters was performed on Fennoscandian collections from all altitudinal zones from nemoral to alpine habitats. C. saniosus collections from different mycorrhiza symbionts were also compared (in particular collections were chosen where just one symbiont was possible). In addition spore size, form and ornamentation were studied on herbarium specimens from selected European herbaria (and even some from USA).

The types of C. aureomarginatus Orton (E) and C. chrysomallus (private herbarium of D. Lamoure) have been examined.

Standard medium for microscopic observations was $2 \% \mathrm{KOH}$ (for some also Melzer's reagent). Spores were observed with a Leitz Laborlux microscope. A random selection of 10 mature spores from gills was measured from each collection, and mean values (MV) of spore length and width from side view (excluding apiculus and ornamentation), as well as Q-values (ratios length to breadth), were obtained. The cap cuticle was studied by mounting in water, then in $2 \% \mathrm{KOH}$. Microscopical drawings were made with the aid of a Leitz Wetzlar tracing device.

Scanning electron microscopy (SEM) preparations of spores (C. aureovelatus) were made from dried specimens. The spores were allowed to swell by submerging a gill first in water, then in $45 \%$ acetic acid, dehydrating first in glacial acetic acid: 100\% ethanol (1:1), then three times in pure $100 \%$ ethanol, and critical point dried in $\mathrm{CO}_{2}$. The preparations were covered with gold-palladium in an argon atmosphere. The scanning pictures were taken with a JEOL JSM 35C at the Electron-Microscopical Unit for Biological Sciences at the University of Oslo.

The colour standards used are those given by Kornerup \& Wanscher (1978) or by Cailleux (1981).

H. Lindström has had the main responsibility for morphological descriptions and discussion of C. saniosus, E. and K. Bendiksen for C. aureovelatus, and E. Larsson has performed the molecular study. 
The collections made by the authors are deposited in the herbaria of the Universities of Oslo $(\mathrm{O})$, Uppsala (UPS) and Oulu (OULU). Fruitbodies used for obtaining sequence data are marked.

\section{Molecular methods}

Thirty-four specimens morphologically belonging to the C. saniosus complex, including C. chrysomallus from the alpine zones and $C$. aureomarginatus from lowland Salix habitat, and further, the closely related $C$. aureovelatus, were selected to represent the variation in morphology, ecology and distribution. In addition the type specimen of C. chrysomallus Lamoure L69-217 (Herb. Lamoure) and the type specimen of C. aureomarginatus P. D. Orton 4026 (E) were included. Cortinarius helobius Romagn. was selected to serve for rooting of phylogenetic trees based upon the assumption, from morphology, that it is close to the C. saniosus complex.

The ITS1, 5.8S, ITS2 regions and approximately 400 base pairs of nuclear LSU rDNA were selected for sequencing. The ITS1 and ITS2 regions have successfully been used to infer relationships among closely related species and species complexes (Chambers et al. 1999, Seidl 2000, Larsson \& Hallenberg 2001, Moser \& Peintner 2002, Peintner et al. 2002, Kytövuori et al. 2005). These regions have been established as suitable target regions for identification of unknown samples (Kõljalg et al 2005) and for characterization of new species (Larsson \& Larsson 1998).

Sequence data were obtained from fresh material or from herbarium specimens (Tab. 1).

Total DNAs were isolated using DNeasy plant mini kit (QIAGEN, Valencia), following manufacturers recommendations. PCR reactions were carried out using Ready-To-Go ${ }^{\mathrm{TM}}$ PCR beads (Amersham Pharmacia Biotech). Primers used to amplify the complete ITS region and the 5'end of the LSU region were ITS1F (Gardes and Bruns 1993) and Lr21 (Hopple and Vilgalys 1999). Standard amplification parameters were: initial denaturation $95^{\circ} \mathrm{C}$ for $5 \mathrm{~s}$, and $94^{\circ} \mathrm{C}$ for $30 \mathrm{~s}, 55^{\circ} \mathrm{C}$ for $30 \mathrm{~s}$, and $72^{\circ} \mathrm{C}$ for $1 \mathrm{~min}$, repeated for 30 cycles.

Amplified products were purified using Qiaqick spin columns (QIAGEN). Primers used for sequencing were ITS1, ITS3, ITS4 (White et al 1990). 50-75 ng of PCR products were used in each sequencing reaction using DTCS Quick Start Kit (Beckman Coulter, Fullerton). Sequences were obtained using CEQ 8000 DNA analysis system (Beckman Coulter). Sequences were edited and assembled using Sequencer 3.1 (Gene Codes, Ann Arbour).

Sequences were aligned using the data editor in PAUP* (Swofford 2003). Gaps for insertiondeletion events were introduced to aid in the alignment. Sequences have been deposited in GenBank and accession numbers are given in Tab. 1.

Heuristic searches for most parsimonious trees were performed using PAUP * . All transformations were considered unordered and equally weighted. Variable regions with ambiguous alignment were excluded, and gaps were treated as missing data except for nine insertion / deletion events that were coded as characters. Heuristic searches with 1000 random-addition sequence replicates, TBR branch swapping, were performed. Relative robustness of clades was assessed by the bootstrap method using 1000 heuristic search replicates with 100 random taxon addition sequence replicates, TBR swapping, saving 100 trees in each replicate. 


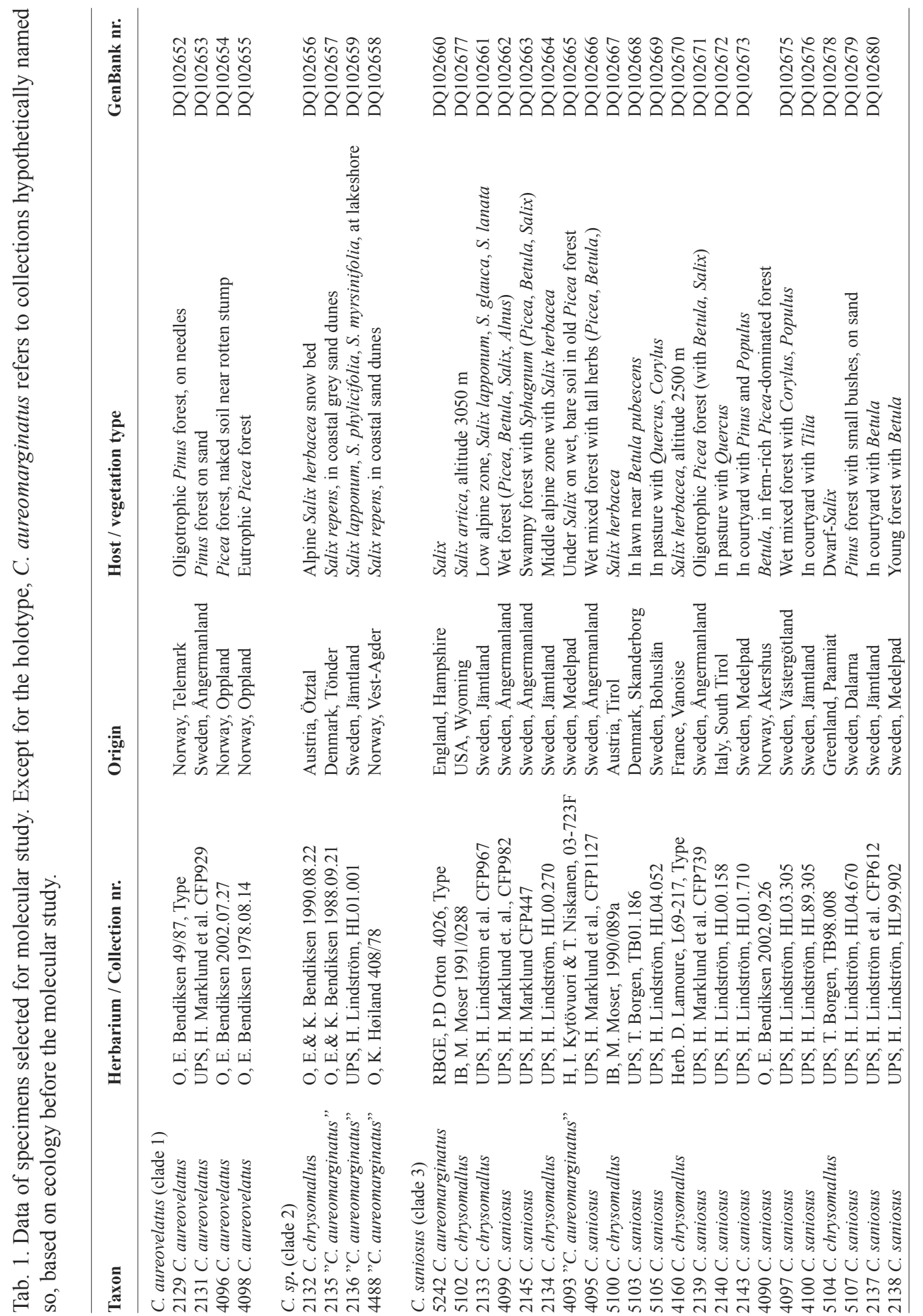




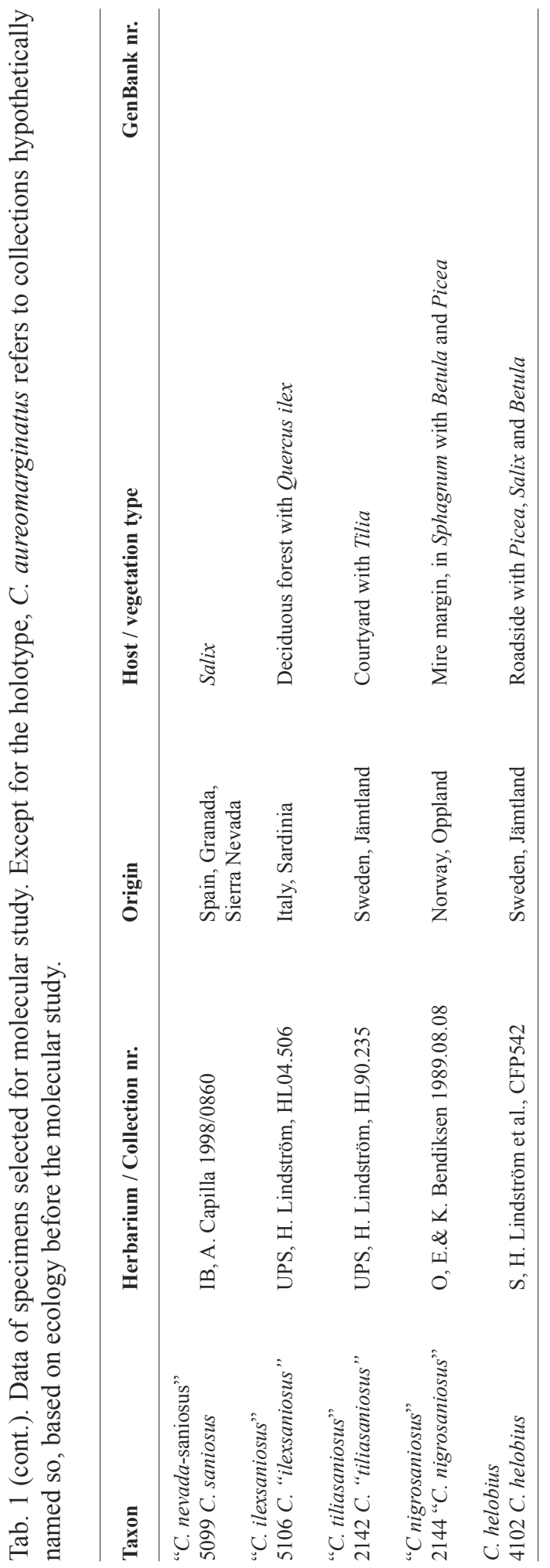




\section{RESULTS}

\section{Morphological analysis}

\section{The Cortinarius saniosus complex}

Comparison of macro morphological descriptions of $C$. saniosus collected from different geographical areas and habitats showed no important differences. This was also the case when the morphology of collections from different mycorrhiza symbionts (Salix, Populus, Betula, Quercus, Tilia) was compared. The diagram (Fig. 1) of spore size of own and herbarium collections from different parts of Europe and USA revealed no differentiation into distinct clusters. The ornamentation pattern was also in the vast majority of specimens of the same rather strong and coarse type (Fig. 2).

A comparison of the morphological descriptions of our own alpine collections called C. chrysomallus and some by Moser (determined as C. chrysomallus) growing with dwarf-Salix with the general description of all $C$. saniosus material revealed no clear differences in macro characters. Few of our collections from the middle alpine zone showed distinct violet tinges on veil and stipe base. The investigation of the spores showed some small differences from those of $C$. saniosus. Spores were, on average, slightly longer and broader than in C. saniosus (from lowland) but a wide overlap was observed (Figs 1, 3). The ornamentation also had a tendency to be lower and coarser than in $C$. saniosus. The spores of the type of C. chrysomallus fell in the middle of the cluster of these alpine collections (Fig. 1).

Some own descriptions of collections from Salix-thickets in the lowlands which for ecological reasons could be named $C$. aureomarginatus were compared with the general descriptions of $C$. saniosus and C. chrysomallus. Again no important differences were found in macro morphology. The spore size and shape which were mentioned in the original description of Orton (1984) were confirmed when we studied the type material. These are, however, not detectable from the scattergram and must be considered as negligible (Fig. 1, 4).

\section{Cortinarius aureovelatus}

In contrast to the $C$. saniosus complex - which has only been observed with deciduous tree symbionts $-C$. aureovelatus has been observed both in coniferous forest and in mountain birch forest. Morphologically this species possessed clear separating characters from C. saniosus, both macroscopically and microscopically. Fruit bodies of $C$. aureovelatus were larger in all aspects and had more reddish brown tinges. The spores were quite different - much more oblong-narrow, and made up a separate cluster in the scattergram (Figs 1, 10-12). The spores were also distinctly less verrucose.

Description of divergent collections

The following observations were made on material that was apparently related to the $C$. saniosus complex, but that deviated in important respects (collections marked with * are DNA examined; collector initials HL refer to Håkan Lindström, EKB to Egil and Katriina Bendiksen; HL-collections are in HL private herbarium):

\section{Divergent collection 1 - interim name "C. tiliasaniosus"}

A very small, yellow-veiled collection found under Tilia in Sweden (Jämtland, Håsjö, Östansjö, Tilia, HL90235)* (and probably in Norway), was characterized by a paler colour and small ellipsoid spores with weak ornamentation (Fig. 6). 


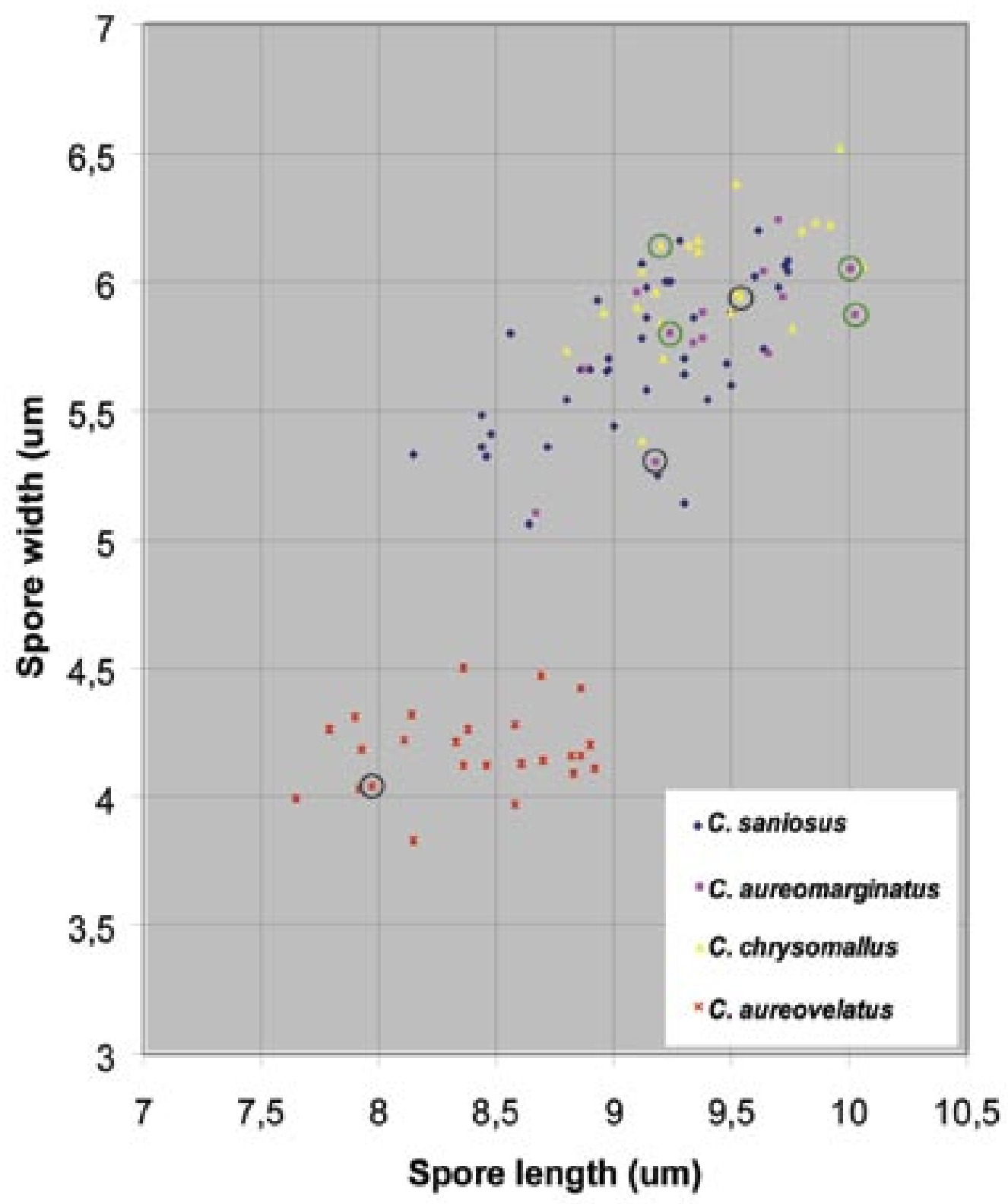

Fig. 1. Spore size variation within the Cortinarius saniosus complex, and C. aureovelatus. Each dot represents the mean value of 10 measured spores from one fruit body. Except for the holotype, $C$. aureomarginatus refers to collections hypothetically named so, based on ecology before the molecular study. Dots with black circles represent type collections. Dots with green circles represent the collections separating as clade 2 in the phylogram. 


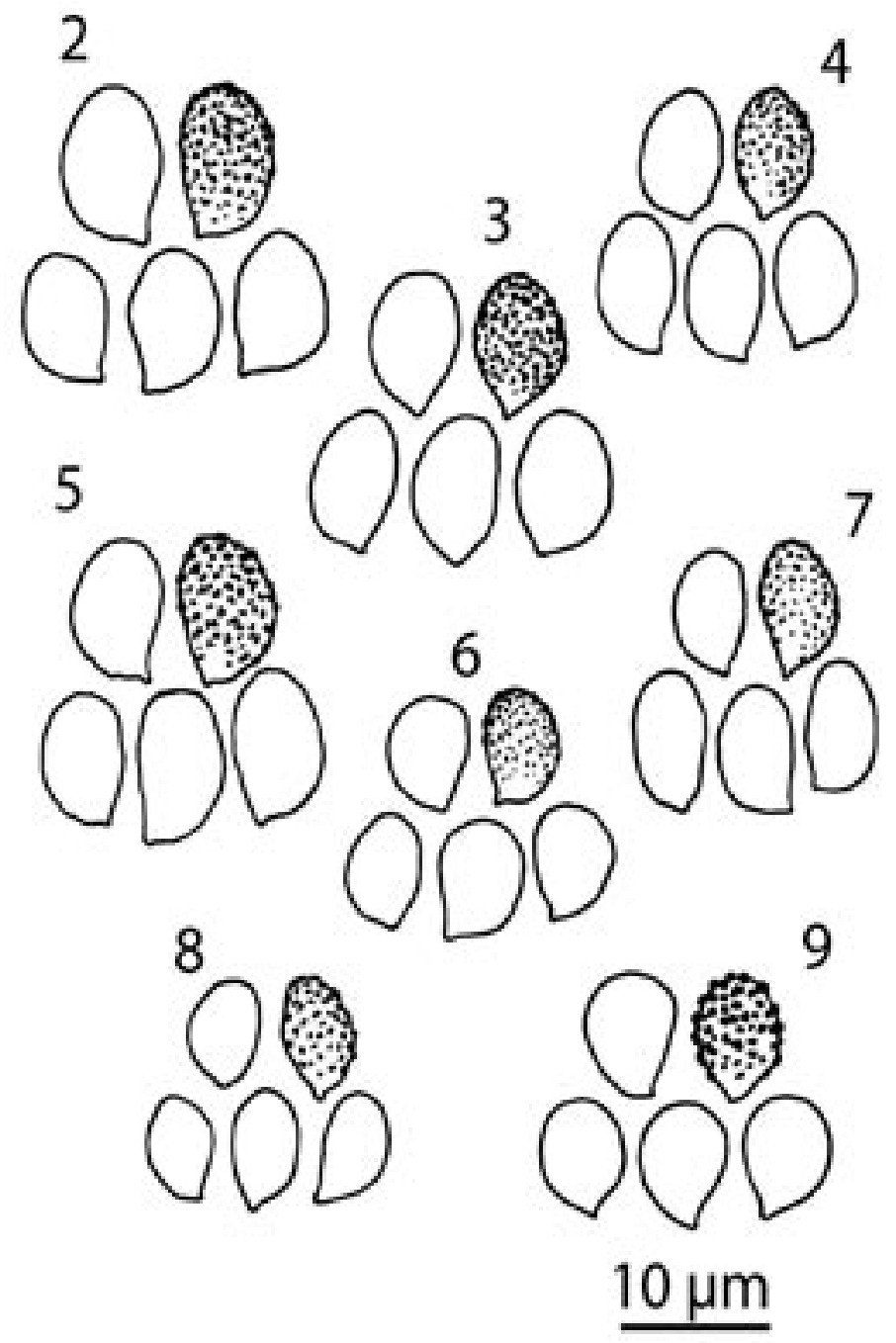

Figs 2-9. Spores of the Cortinarius saniosus complex. Fig. 2. C. saniosus (Cortin. Flora Photog. project 447 (UPS)). Fig. 3. Holotype of C. chrysomallus (D. Lamoure 69-217 (Herb D. Lamoure)). Fig. 4. Holotype of C. aureomarginatus (P.D. Orton 4026 (E). Fig. 5. "C. saniosus" (clade 2) (K. Høiland 408-78 (O)). Fig. 6. "C. tiliasaniosus" (HL90.235 (Herb H. Lindström)). Fig. 7. "C. nigrosaniosus" (E. and K. Bendiksen 08.08.89 (O)). Fig. 8. C. "ilexsaniosus" (HL04.425 (Herb H. Lindström)). Fig. 9. "C. nevadasaniosus" (A. Capilla (IB98/0860)).

\section{Divergent collection 2 - interim name "C. nigrosaniosus"}

One collection (Norway: Oppland, Lunner, mire margin, Betula, Picea, EKB 08.08.89(O)*) differed from typical $C$. saniosus by having a darker, almost blackish cap colour and more narrow, ellipsoid spores (Fig. 7). This material was also recognizable by a somewhat deviating ecology; under Betula 


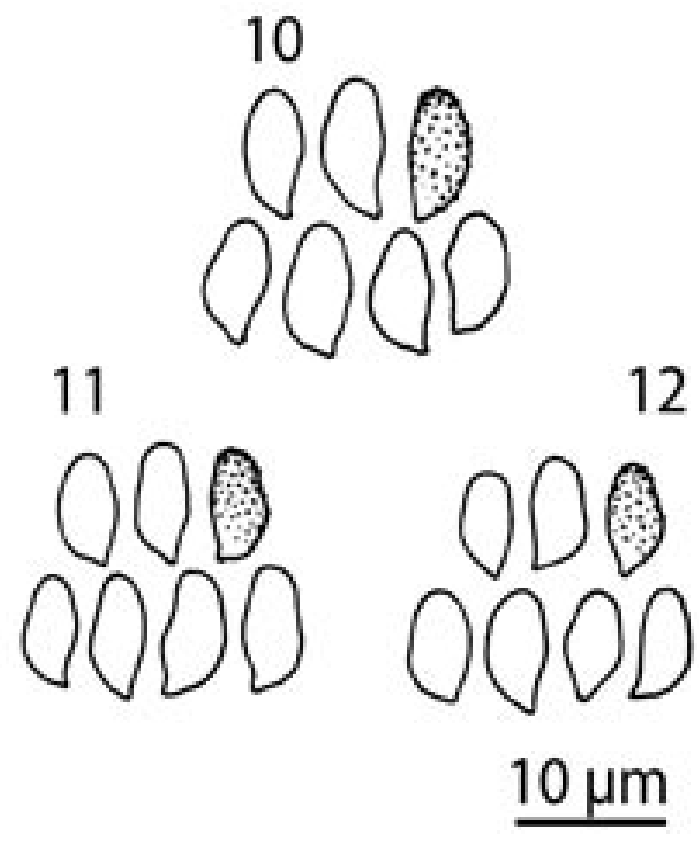

Figs 10-12. Spores of Cortinarius aureovelatus. Fig. 10. E. Bendiksen 49/87 (holotypus) (O). Fig. 11. E. Bendiksen 27.07.02 (O). Fig. 12. K. Metsänheimo 20.08.84 (OULU).

in oligotrophic mire margins surrounded by nutrient poor spruce forests.

Divergent collection 3 - interim name "C. ilexsaniosus"

C. saniosus-like material found in Quercus ilex forest in Sardinia, Italy (Sardinia, Nuoro, Obvoida, Quercus ilex, HL04.425*; D:o, Gavoi, Q. ilex HL04.406) was characterized by small size, yellow veil, fibrillose cap and particularly small and narrow spores (Fig. 8).

Divergent collection 4 - interim name "C. nevadasaniosus"

A collection from South Spain, with interim name C. "nevadasaniosus" (Granada, Sierra Nevada, Huéneja, Salix, A. Capilla, (IB98/0860, named C. saniosus)*), is said to be collected under Salix, with rather pale colours and a yellow veil. The spores were clearly separated with an almost round shape and very strong ornamentation (Fig. 9).

\section{Molecular analyses}

The alignment of the 35 specimens was 1014 characters long. After exclusion of ambiguous areas 840 characters remained for the analysis, of which 748 were constant, 49 were variable and parsimony uninformative, and 34 were parsimony informative. Nine gaps were coded as characters giving a total of 43 parsimony informative characters. 
The phylogenetic analysis yielded 318 equally most parsimonious trees (length $=100, \mathrm{CI}=$ $0.9000, \mathrm{RI}=0.9206$ ). Fig. 13 shows one of the 318 equally most parsimonious trees presented as a phylogram. Bootstrap support above $60 \%$ is indicated on branches.

The bootstrap analysis recovered three major supported clades. Clade 1 with $97 \%$ bootstrap support corresponds to $C$. saniosus, clade 2 with $88 \%$ bootstrap support is a cluster of specimens determined as $C$. saniosus, $C$. chrysomallus and $C$. aureomarginatus, clade 3 with $68 \%$ bootstraps support corresponds to the new species $C$. aureovelatus. The sequence of collection HL04.506 ( $C$. "ilexsaniosus") clusters with the sequence of collection HL90.235 (C. "tiliasaniosus") with 89\% bootstrap support, whereas Capilla 98/0860 (C. "nevadasaniosus”) and EKB 890808 (C. "nigrosaniosus") occur on single branches.

\section{DISCUSSION}

Clade 1, with $97 \%$ bootstrap support, includes 22 sequences of specimens mainly determined as $C$. saniosus. The specimens are collected in different biotopes, from different symbionts (Betula, Tilia, Quercus etc), and from different geographical areas. The use of the name C. saniosus for a taxon thus circumscribed is in accordance with the opinion of Moser and other mycologists (Kühner \& Romagnesi 1953, Moser 1983). However, collections from dwarf-Salix in alpine regions determined as $C$. chrysomallus also enter this cluster, including the sequence of the type specimen of C. chrysomallus. Furthermore, the sequence of the type specimen of $C$. aureomarginatus also clusters in this clade. The molecular data thus clearly show that $C$. saniosus is a species that occurs in a great variety of habitats from the nemoral to the alpine zones, associated with many host trees. This result is in agreement with the morphological results which fail to reveal any important difference among these collections. The alpine C. chrysomallus is said to differ by violet tinges on veil and stipe base (Lamoure 1977). This character was found not to be reliable. This is in agreement with observations made by Moser \& McKnight (1987); compare also remarks by D. Lamoure in the original description (loc. cit.). Moreover, the violet-bluish tinges in Telamonia are known to be unstable morphological characters and can be variable even between years on the same mycelium. Futher the slight spore differences we found do not seem to be enough to separate $C$. chrysomallus on a species level according to a morphological species concept.

C. aureomarginatus was described by P. D. Orton as a C. saniosus-like species growing under Salix in the lowlands of South England. The conclusion is that our Salix collections from lowlands, named C. aureomarginatus, are not morphologically distinguishable from C. saniosus on a morphological base.

The results suggest that C. chrysomallus and C. aureomarginatus should be regarded as synonyms to $C$. saniosus. Within this clade there are small sequence divergences. However, the variation could not be connected to host speciation or geographical distribution and will here be regarded as variation within one species.

Clade 2, with $88 \%$ bootstrap support. The sequences of the three specimens determined as C. aureomarginatus HL01.001, C. saniosus EKB 88.0921 and C. saniosus KH 408.78, cluster with a bootstrap support of $80 \%$. Two specimens are collected from Salix repens vegetation at sea shore (Norway, Denmark) and one from lake shore (Sweden). The Norwegian collection included in the material is published as C. ammophilus Pearson by Høiland (1975), later revised as C. saniosus (Høiland 1980 and herb O). The fourth collection, determined as C. chrysomallus (confirmed by M. Moser), EKB 90.0822, is from high altitudes in the Alps. Despite considerable efforts, we have not 


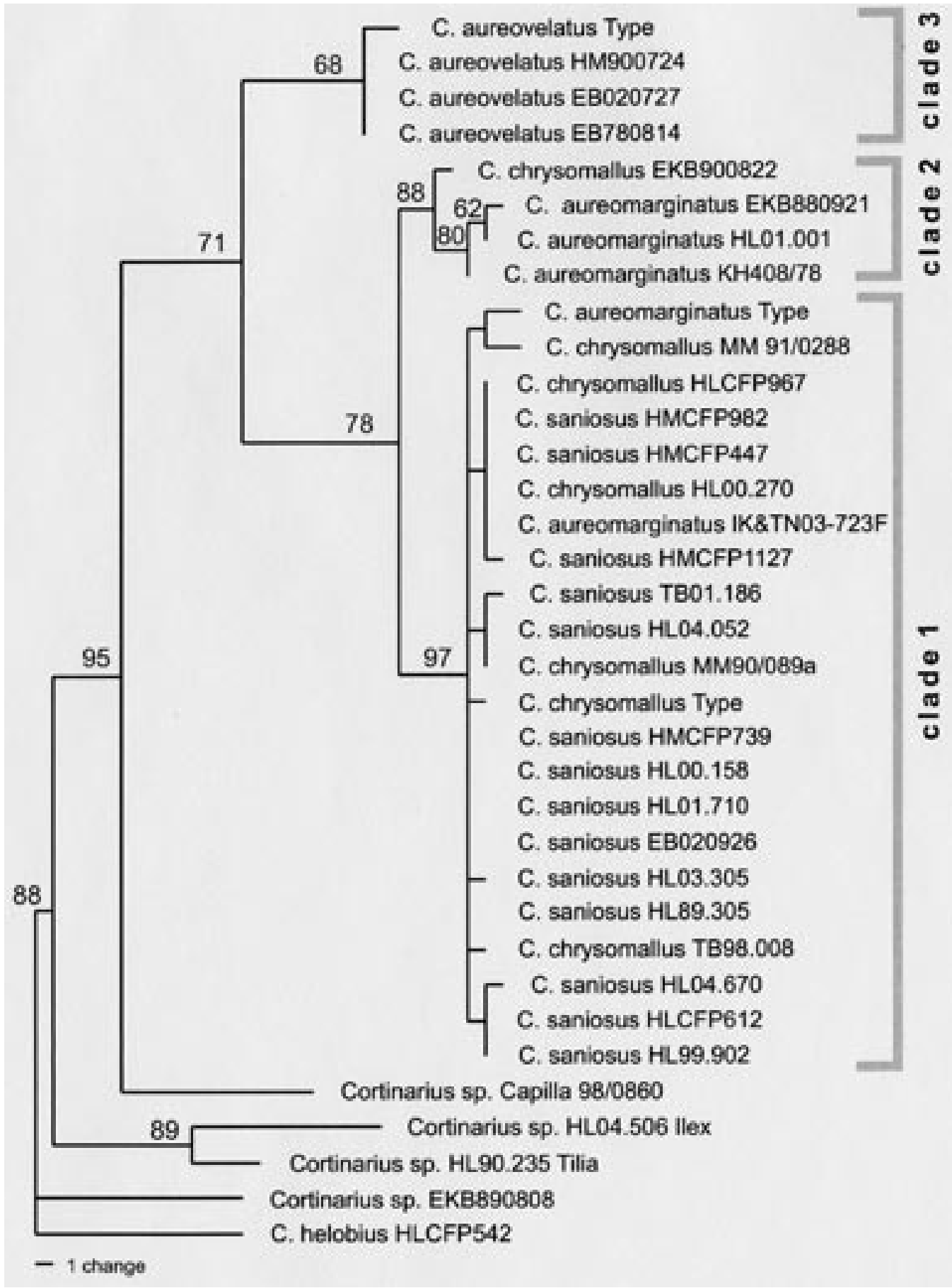

Fig. 13. One of 318 equally most parsimonious trees presented as a phylogram showing relative branch lengths (tree length $=100, \mathrm{CI}=0.9000, \mathrm{RI}=0.9206$ ). Cortinarius helobius is used as outgroup. Bootstrap values greater than $60 \%$ are noted. Except for the holotype, $C$. aureomarginatus refers to collections hypothetically named so, based on ecology before the molecular study. 
managed to find any morphological characters separating these collections from the ones included in clade 1 (e.g. spores, cf. Fig. 5). Ecologically the four collections are found with Salix, but clade 1 also contains collections both from alpine and lowland Salix habitats.

Clade 1 and clade 2 cluster with a bootstrap support of $78 \%$, suggesting a close relationship. The sequence difference however, between clade 2 and clade 1 , is 8 substitutions, two single deletions, one 4 base pair deletion, one 5 base pair deletion and one single insertion. This sequence divergence must be considered rather high for within species divergence, and the molecular data indicate that clade 2 should be regarded as a taxon separated from $C$. saniosus. Further investigations and analyses are needed before conclusions about the taxonomic implications of this clade can be drawn.

Clade 3, with $68 \%$ bootstrap, comprises sequences for four specimens that are identical in the ITS 1 and ITS2 regions. The sequence divergence between clade 3 and clade 1 is 7 substitutions, two single insertions, one single deletion, one 2 base pair deletion and one 3 base pair deletion. Futhermore this taxon is well separated from $C$. saniosus according to a morphological species concept. The sequence divergence and differences in morphological characters support the description of the new species $C$. aureovelatus.

Collections HL04.506 (C. “ilexsaniosus") and HL90.235 (C. "tiliasaniosus") cluster with $89 \%$ bootstrap support. Sequence divergence between the two collections is 11 substitutions, five single, two 2 base pair and one 3 base pair insertion / deletion events. This divergence is fairly high indicating that they should be regarded as two separate taxa: representing two more distantly related species. This is in agreement with the morphology (see above). The same is true for collections on single branches; Capilla 98/0860 (C. "nevadasaniosus") and EKB 890808 (C. "nigrosaniosus").

As strongly indicated from the molecular study, at least one cryptic species has been discerned within the data set, in the sense of Taylor et al. (2000). As pointed out by these authors, once progeny evolutionary species have formed from an ancestor, changes in gene sequences occur and can be recognized before changes have occurred in mating behavior or morphology. As already shown in our study of spores, some smaller morphological differences may exist, and more may possibly be found by detailed studies when more material will be available.

\section{TAXONOMY}

Key to the species

1. Fruitbodies small, yellowish brown, cap $0.5-3 \mathrm{~cm}$, stem $1-5 \mathrm{~mm}$ broad, mainly in deciduous forest. Spores ellipsoid-broadly ellipsoid, $8.5-10$ x 5-6.5 $\mu \mathrm{m}, \mathrm{Q}=1.5-1.8$, rather strongly and coarsely verrucose C. saniosus

1. Fruitbodies rather robust, more reddish brown, cap 2-5 cm, stem 4-9 $\mathrm{mm}$ broad, mainly in conifereous forest. Spores narrowly ellipsoid, 7.5-9 x 4-4.5 $\mu \mathrm{m}, \mathrm{Q}=1.8-2.2$, finely to moderately verrucose

C. aureovelatus

Descriptions of species

C. saniosus (Fr.: Fr.) Fr. 
Agaricus saniosus Fr.: Fr. (1821) Syst. Mycol. I: 232. - Cortinarius saniosus Fr. (1838) Epicr:313. Type: not designed. - Cortinarius chrysomallus D. Lamoure 1977: 135. Type: France, Vanoise, Plan de Vallonet, sous le Glacier de la Patinoire, 2500 m, 1969.09.08, L. 69-217 (Herb. D. Lamoure). - Cortinarius aureomarginatus Pearson ex P.D. Orton 1984: 566. Type: Great Britain, Hampshire, New Forest, Park Dale, 1970.08.30, Orton 4026 (E).

Figs 2-4 (spores).

Description. Cap: $0.5-3(3.5) \mathrm{cm}$ broad, conical to campanulate, later broadly conical to planoconvex, often with a small but distinct umbo, at margin first curved downward, with age commonly depressed around the umbo, often undulate and sometimes cracked; surface when young finely fibrillose from yellow veil, giving an almost marbled impression (especially visible in centre when drying); with age more or less smooth and somewhat shining, with veil fibrils in outermost margin; seldom with striae from translucent gills (but can be visible up to half the distance to centre); hygrophanous, in moist condition dark yellow-brown to chestnut brown or saturated red-brown (more red-brown with age) (R47, S47, S 69, S67), centre mostly darker, almost blackish brown (T50, T70, T30 or darker), sometimes most of the cap darkening or with dark spots, margin lighter yellow-brown, drying concentrically from centre but also from margin, when dry reddish yellow-brown to brownish yellow (P47, P45, P65), centre more red-brown (T20). Gills: 2-3.2 mm broad, intermediate to subdistant, emarginate with a tooth to more or less broadly adnate, sometimes faintly decurrent, pale yellowish (M60) to pale greyish ochre (M65), very rarely with greyish violet tinge, later darker ochraceous (N60, P60 but more yellowish) to pale yellowish brown; gill edge, even concolourous or paler yellowish. Stipe: $10-40(-70) / 1-5 \mathrm{~mm}$, cylindrical or with somewhat clavate base, sometimes weakly radicating, rather stiff, with rather rough, silvery greyish white fibres, uppermost part shining and pale greyish ochre to pale greyish (M53, K51, K73), rarely with a tinge of bluish violet, in lower part more yellowish fibres on light yellowish brown to golden ochraceous (M69), at base dirty yellowish brown (N, P65) and later becoming darker to almost black (T50), especially when touched, and sometimes with a white, rarely violet, felt of mycelium. Veil rather richly developed, golden yellow, at first almost socklike (up to $2 / 3$ of stipe), then with a protruding ring zone and cracking in belts below, later fibrous and fugacious, sometimes as an even shining yellowish cover. Flesh: in cap thin, in stipe somewhat looser in the core and often hollow with age, in cap dark brownish yellow to dark chestnut brown - grey brown (P45, S47, T50), in top of stem ochraceous (M69, P60; P67), rarely with a bluish violet tinge, in outer cortex golden yellow to golden brown, downwards yellowish brown (N57), in base (S50) and darkening to almost black. Smell not distinct (sometimes a little tinge of earth or radish). Spores (8.1)8.5-10.0(10.1) x (5.0)5.3-6.3(6.6) $\mu \mathrm{m}$, ellipsoid to broadly ellipsoid, L/W (Q) = 1.5-1.7, rather strongly and coarsely verrucose. Gill edge fertile with (2-) 4 spored basidia, sterigmata up to $8 \mu \mathrm{m}$, with shorter and small cylindrical to clavate (-bulbous) sterile cells. Cap cuticle with thin epicutis (7-20 $\mu \mathrm{m}$ ), 2-4 layers, hyphae (3)5-7(10) $\mu \mathrm{m}$ broad, strongly cross-striped to granular incrusted; hypodermium rather strongly developed (about 5-7 layers), elements shortly rectangular, 15-30 (35) x 35-65(90) $\mu \mathrm{m}$, with thick-wall pigments (thick brown walls) with plaques, in lower part with some narrow finely granulated hyphae $(2-3 \mu \mathrm{m}$ broad); trama hyphae more irregular with a mixture of broader (up to $20(-25) \mu \mathrm{m}$ ), weakly pigmented elements and narrow (about $5 \mu \mathrm{m}$ broad) elements with more distinct thick-wall and granular pigments.

Ecology and distribution. C. saniosus is a widely distributed species, reported from different parts of both Europe and North America (cf. survey in Garnier 1992, Moser \& McKnight (1987), Moser (1993) and Borgen (1998) (as C. chrysomallus)). It has also a very wide ecology along the altitudinal gradient, growing from sea level to high up in the mountains and associated with a wide range of deciduous trees, including Salix (tree, shrub and dwarf-shrub species), Populus, Betula, Quercus and Tilia. C. saniosus is usually abundant on bare soil or in low mosses, but is sometimes growing in Sphagnum. It occurs on both acid and calcareous ground. Only few other species have been reported to grow with Salix all the way from lowlands to alpine dwarf-Salix shrubs. Arnolds \& 
Kuyper (1995) divided Salix-associated Cortinarius species in six ecological groups. One of them includes $C$. cavipes, C. comatus, $C$. cucumisporus and $C$. pauperculus, reported to grow both with $S$. repens in the lowlands and with dwarf willows in the arctic and alpine zones. Another group with species having a wider host range than Salix spp. includes a.o. C. casimiri and C. parvannulatus. There are similar observations with ectomycorrhizal fungi from some other genera (and associated with various host trees); e.g. Russula, cf. R. pascua (Watling 1992). Russula nana Killerman, which was believed to be a strict alpine/subalpine species, has been shown to be a species also growing in the lowlands in North European Picea abies forests with Betula in mire edges (cf. Sarnari 1998, J. Ruotsalainen, pers. comm.). There may be more ectomycorrhizal species described from the alpine zones which are not separable from species described from the lowlands. Lowland - versus arctic - alpine Telamonia species is further discussed by Bendiksen et al. (1993).

Nomenclatural note. There is a nomenclatoral problem with the name $C$. saniosus. The epithet is sanctioned, first published in Fries Systema Mycologicum Fries (1821:232). The description is based on a simple collection by Fries from spruce forest. The problematic character mentioned by Fries is that he found a sort of blood red milky substance downward the stipe ("compressus liquorem sanguineum fundit"), which is also reflected in the epithet (saniosus). This character has not been found in the actual species for which we use the name. Our species is mainly associated with deciduous trees but not infrequently growing in mixed forest with spruce or reported from coniferous forest. In the Epicrisis Fries (1838: 313) more clearly describes a species which fully suits with our species. This problem is discussed by Melot (1995) and he concluded that the name should not be used. Later J. Melot (pers. comm.) has changed his mind and now accepts the epithet. The name C. saniosus has a long tradition of being used for our taxon (e.g. Lange 1938, Lundell \& Nannfeldt 1979: Fungi exsiccati No. 2835-6, Moser 1983). We will here follow this tradition and use the name in this sense.

Specimens examined (collections marked with * are DNA examined; "CFP" refers to the collection of Cortinarius Flora Photographica project. Collector initials HL refer to Håkan Lindström, EB to Egil Bendiksen, EKB to Egil and Katriina Bendiksen, TEB to Tor Erik Brandrud, KH to Klaus Høiland and TB to Torbjørn Borgen. HL-collections are in HL private herbarium except those marked UPS. Names inside quotation marks are our hypothetical names based on ecology before the molecular study. The list also includes the identified clade 2 collections. The description is based on the clade 1 collections, but so far we cannot see any substantial difference from the few available descriptions of the clade 2 collections): Sweden: Bohuslän, Grebbestad, Lammön, Quercus, Corylus HL04.052 (UPS)*; Västergötland, Älgarås, Unden, HL03.305; Dalarna, Rättvik, Rättviksheden, HL04.670; Medelpad, Timrå, Lövudden, Betula, HL99.902 (UPS)*; D:o, Selånger, Silje gård, Quercus, HL90.036 (UPS); D:o, Timrå, Vistavarv, Betula, Mu90.012; D:o Populus, Siw Muskos 90-14; D:o, Njurunda, Döviksjön, HL85.713; Tynderö, Holmö, CFP961 (UPS); D:o, Sundsvall, Sidsjön, Betula, CFP262 (UPS); D.o, Torp, Hammar, Betula, HL98.808; D:o, Torp, Hammar Populus, HL01.710 (UPS)*; D:o, Torp, Hammarsmon, HL01.739; D.o, Stormyrtjärn, lakeside, Salix, HL90.236 (“aureomarginatus”); D:o, Haverö, Björntjärn, in moist depression with Salix, Tuula Niskanen 03-723F (UPS)*, (“aureomarginatus"); Jämtland, Ragunda, Pålgård at churchyard, Betula, HL87.125; D:o Hammarstrand by the river, Salix nigricans, HL90.098 (“aureomarginatus"); D:o, Hällesjö, Albacken, riverside, Salix, HL90.132 (“aureomarginatus"); D:o, Bräcke, Grötingen, Betula, 90.019; D:o Håsjö, Östansjö, Tilia, HL 89.305 (UPS)*; D:o HL00.010; HL90.011; D:o, Betula, HL86-24; D:o HL90.146; D:o, Kälarne, Betula, CFP612 (UPS)*; Jämtland, Håsjö, Östansjö, Lillsjön, hällarna, Salix, HL96.728 (“aureomarginatus"); Jämtland, Håsjö, Singsjön, lakeshore, HL01.001* (“aureomarginatus”); D:o, Undersåker, Välliste, middle alpine zone, Salix herbacea CFP701 (UPS) (“chrysomallus”); D:o, low alpine zone, Salix glauca; CFP700 (UPS) ("chrysomallus"), D:o, Åre, Åreskutan, Salix herbacea HL88.026 (“chrysomallus"); D:o, Frostviken, S Stekkenjokk, Salix herbacea, HL90.134 (“chrysomallus”); D:o, low alpine zone, Salix lanata, S. glauca, CFP967, (UPS)* (“chrysomallus "); D:o, middle alpine zone, Salix herbacea, HL00.270 (UPS)*, (“chrysomallus”); Ångermanland, Tåsjö sn, Brattbäcken, HL88.728; D:o, Stigsjö, Rosendalsbäcken, CFP689; D:o, Säbro, Åm, Salix, Betula, CFP982 (UPS)*; D:o Saltvik, CFP754 (UPS); D:o, Betula, Salix CFP739 (UPS)*; D:o, Hårsta, CFP 447, Betula, Salix, in Sphagnum (UPS)*; D:o, Häggdånger, Sjö, Betula, CFP1127 (UPS)*; D:o, Graninge, Graninge bruk, Betula, HL90.013; Västerbotten, Holmsjön sn, Obbola, Tilia, HL80.047; D:o, Jörn, Missenträsk, Salix, CFP1123 (UPS), (“aureomarginatus"). Norway: Akershus, Bærum, roadside by Picea forest, KH 26.09.79 (O 123902); Akershus, Oppegård, fern-rich Picea forest, with Betula, EB 26.09.02 (O)* (not microscoped); Vestfold, Tjøme, eutrophic Quercus forest with Tilia, TEB 91-82 (O); Telemark, Kragerø, eutrophic Quercus forest, under Populus, TEB 242-87 (O 123913); Aust-Agder, Gjerstad, eutrophic Picea forest with Populus, TEB 195-87 (O 123905); Vest-Agder, Farsund, Lista, Havik, sand dune depression, Salix repens, KH 408-78 (O 123908)* ("aureomarginatus "); D:o, Lista, Lomsesanden, sandy depression between Salix repens dunes, KH 27.09.72 (O 123899) ("aureomarginatus"); D: o, Lista, Kviljo, sand dune depression, Salix repens, KH 26.07.78 (O 123903) ("aureomarginatus"); D:o, Lista, Einarsneset, 
sand dune, Salix repens, R. and K. Høiland 11.10.86 (O 123910) ("aureomarginatus"); Rogaland, Sola, eutrophic QuercusCorylus forest, TEB 110-82 (O); Hordaland, Granvin, Håstabba, roadside, Salix, Betula, EB 286/05 (O); Sogn og Fjordane, Sogndal, Reppanipa, low alpine zone, Salix, Betula, EKB 10.09.00 (O); Sør-Trøndelag, Oppdal, Kongsvoll, middle alpine zone, HL94.728 ("chrysomallus"); Nordland, Saltdal, low alpine zone, Salix herbacea snow-bed, EKB 527/88 (O) (as chrysomallus); D:o Salix herbacea snow-bed, EKB 528/88 (O) (as chrysomallus); Finnmark, Vadsø, Annejåkka, riverside, Salix glauca, S. lanata, KH and K. Østmoe 03.08.79 (O 123914). Denmark: Skanderborg, Silkeborg, Betula, TB01.186, (Herb TBorgen)*; Tønder, Rømø, grey dune, Salix repens var. arenaria, EKB 88.0921 (O)* (“aureomarginatus"). Great Britain: Hampshire, New Forest, Park Dale, 1970.08.30, Salix, P.D. Orton 4026, C. aureomarginatus, holotypus (E)*. Netherlands: Friesland, at seaside, Salix repens, HL87.127. Poland: Nat. Park Bialowieza, Mischwald, M. Moser, 67/157 (IB). France: Vanoise, Plan de Vallonet, sous le Glacier de la Patinoire, 2500 m, L. 69-217, C. chrysomallus, holotypus, (Herb D. Lamoure)*. Austria: Tirol, Timmelsjoch, Banker Alpe, (S. herbacea) M. Moser 1990/089a (IB)* (as C. chrysomallus); Ötztal, Salix herbacea snow-bed, EKB 90.0822/1 (O)* (as chrysomallus); D:o, Salix herbacea snow-bed, EKB 90.0822/2 (O) (as chrysomallus). Italy: South Tirol, Aura, Kaltern, Quercus, HL00.158, (UPS)*. Greenland: Söndre Strömsfjord, 46.08.08, Salix glauca, Lange 46.248 (H T Borgen) (as chrysomallus); Paamiut, E of Paamiut, S. herbacea, TB93.130; (as chrysomallus); D:o, Paamiut, S. herbacea, TB98.036, (as chrysomallus); D:o, dwarf-Salix TB98.008, (herb TBorgen)* (as chrysomallus); USA: California, Humboldt Co., near Eureka, sand dunes on Samoa peninsula, Pinus murrayana, Salix hookeriana, M. Moser, 1991/0596 (IB) (as chrysomallus); D:o, Wyoming, Beartooth Mountains, Beartooth Pass, 3600 m, Salix, M. Moser, 83/330 (IB) (as chrysomallus); D:o, Shoshona Ntl. Forest, Two Ocean Mts., 3050 m, Salix arctica, M. Moser, 1991/0288 (IB)* (as chrysomallus) (cf. Moser \& McKnight 1987, Moser 1993).

Cortinarius aureovelatus Bendiksen, K. Bendiksen \& H. Lindstr. sp. nov.

Pileus 1.8-5 (-7.5) cm latus, convexus, interdum umbonatus saepe irregularis, margine incurvo, postea plane convexo vel complanato, plus minus ochraceo, cuticula glabra, hygrophana, madida obscura, sed vivida rubrobrunnea, raro ochraceo-brunneola, umbo fere fusco, margine raro striato, in sicco aurantiobrunneo vel pallide ochraceo-brunneo, saepe nigrescente maculato. Lamellae 3-7 mm latae, intermediae confertae vel subdistantes, vivide ochracea. Stipes 40-75 x 4-9 mm, satis planus, saepe tortuosus, interdum leviter clavatus vel basin versus acutus, velo flavo, subtiliter squamato. Caro pallide ochracea, odor et sapor haud vel leviter distinctus. Sporae 7-9 (-9.5) x 3.5-4.5 (-5) $\mu m$, tenuiter ellipsoideae, paulo vel moderate verrucosae.

Hab.: ad terram in silvis, imprimis coniferarum et in zonae subalpinae cum Betula pubescenti ssp. czerepanovii.

Holotypus: Norway. Telemark: Fyresdal, Napetjern N, west of Sandvassåi, path border in oligotrophic forest of Pinus sylvestris, ca 630 m a.s.l., UTM ML 56 62, 18 Aug. 1987, E. Bendiksen 49/87(O).

Figs 14-16 (habitus), 17, 10-12 (spores).

Description. Cap: $1.8-5.0(-7.5) \mathrm{cm}$ broad, when young convex to umbonate with incurved margin, later planoconvex to flattened or even depressed, sometimes with a broad umbo, form often irregular; young fibrillose from a rather fugacious, yellow veil, most persistent in margin, later smooth, sometimes secondary fine scaly by age; hygrophanous, in moist condition the main part mostly rather dark, but vivid red-brown, sometimes more yellowish brown (S29-35-37-49(-T39)-6E7-8), toward centre darker (7F6-8, T30), umbo almost black, decoloration sometimes uniform, sometimes in a radiating pattern outside umbo with most persistently dark colours, especially in the process of drying with typical blackish spots; striae from translucent gills only faintly visible in uttermost margin of thin fleshed specimens, in a drying phase rather vividly orange brown (P40, R40), at last pale yellowish brown. Gills: 3-7 mm broad, intermediate to subdistant, emarginate with a tooth to more or less broadly adnate, regular to rather uneven, vividly ochraceous (M-N77), margin paler. Stipe: 40-75/4-9 mm, rather even and often tortuous, sometimes faintly clavate or acute at base; upper part greyish pale and shiny, lower part covered by abundant veil, as young ending in an adpressed ringlike zone, downwards as zigzag zones or as a more uniform cover; strongly golden yellow, 4A6-5A5, L60. Flesh: compact, at first ocharaceous pale, later with golden to rusty brown tinges, taste mild, no distinct smell. Spores: (7.6)7.9-8.7(9.0) x (3.8)4-4.5 $\mu \mathrm{m}$, narrowly ellipsoid, L/W (Q) = 1.8-2.2, 


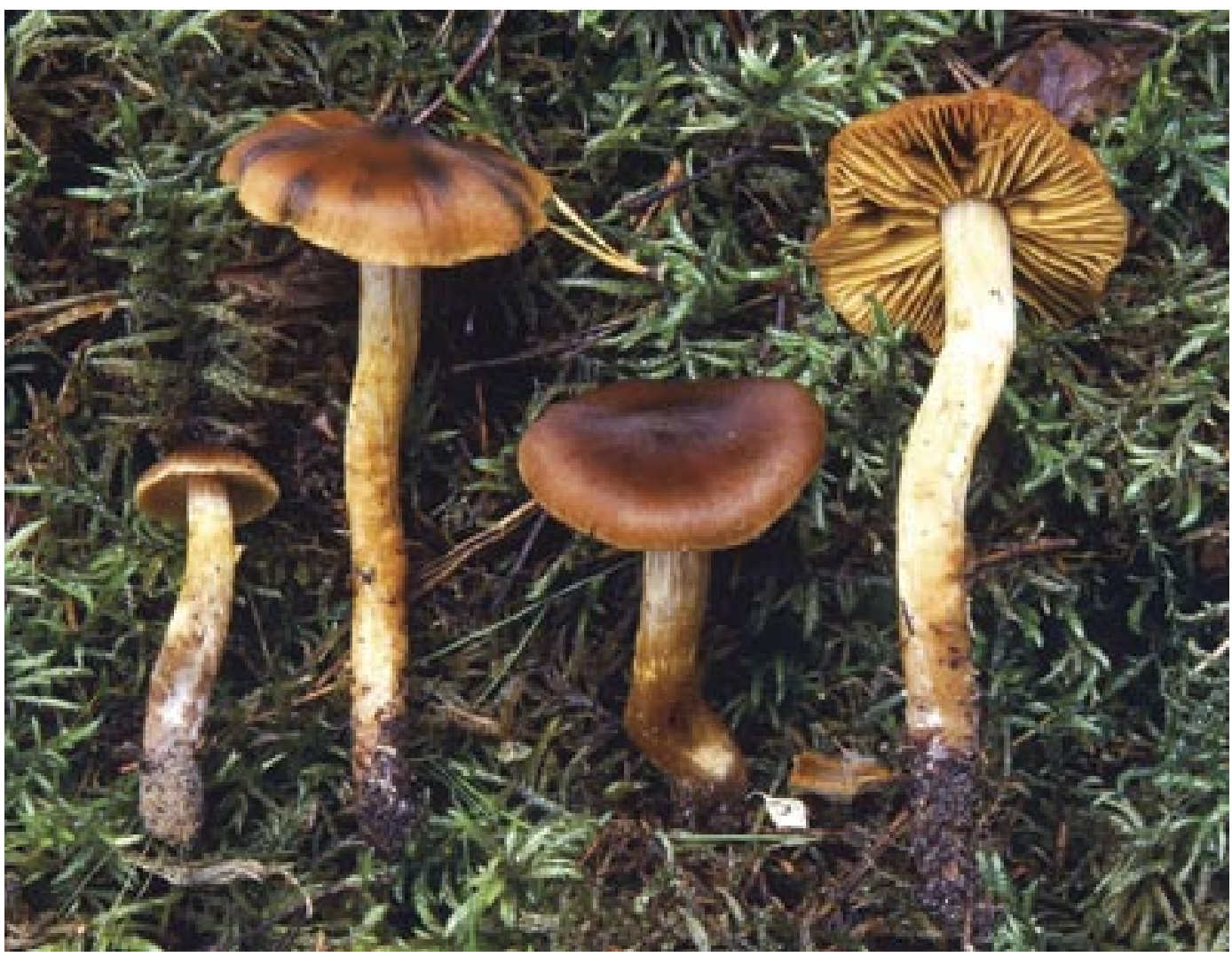

Fig. 14. Cortinarius aureovelatus, Norway: Akershus, Nannestad, 26.09.87, T.E. Brandrud 346-87 (O). Photo: T.E. Brandrud.

often somewhat irregular, finely to moderately verrucose. Gill edge fertile, sometimes with abundant clavate sterile cells. Cap cuticle: smooth, radially arranged, epicutis well differentiated, 2-4 layers, hyphae $8-10 \mu \mathrm{m}$ broad, zebra-striped, encrusted, with clamp connections, as a layer above a thicker, brownish hypoderm, membranaceous, not zebra-striped, hyphae 12-20 $\mu \mathrm{m}$ broad. Hymenophoral trama regular, with inflated cells up to ca. $25 \mu \mathrm{m}$.

Ecology and distribution. The species has a wide ecological amplitude both along a zonal temperature gradient (south-north and altitudinal) and a local nutrient gradient. Till now the species is only known from Norway, Sweden and Finland, and it might be a northern species, although it does not seem to have a northern tendency inside of Fennoscandia.

It has been found from coniferous forests in the southern boreal zone in southernmost Norway and southernmost Finland (Kytövuori pers. comm.) to northern boreal birch forests in northern Finland and from dry Pinus forest (xeric, Cladina-dominated) to submesic forests of Picea or Betula.

However, the species prefers naked soil, as may be typical in eutrophic, dense and shady low herb spruce forests or in dry, often sandy pine forests. Often it is associated with disturbed places, along small tracks a.s.o. In spruce forest areas it may at first seem to be restricted to rich ground. It seems to avoid thick moss carpets in bilberry spruce forest and in the few cases where it appears in 
15
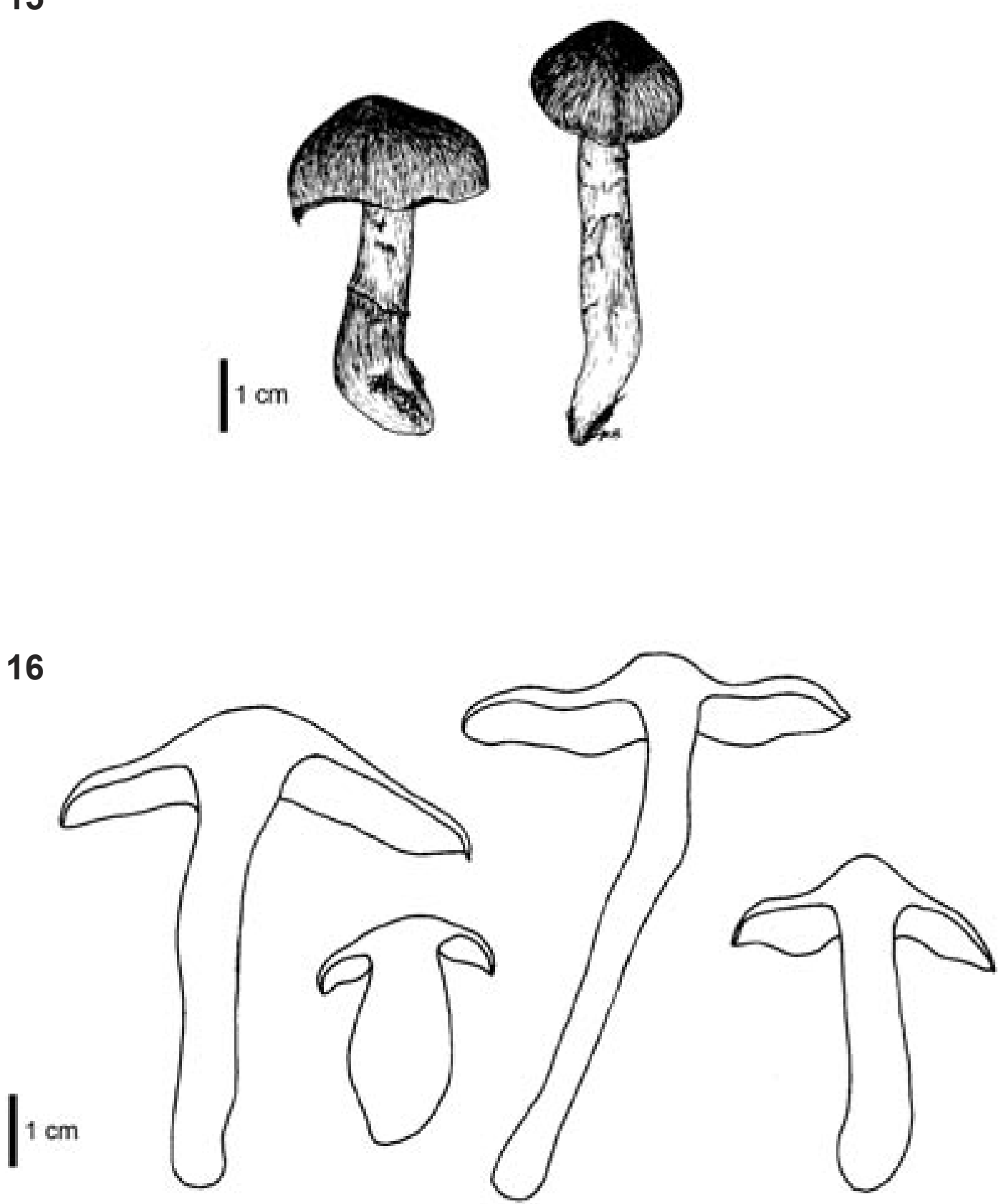

Figs 15-16. Cortinarius aureovelatus. Fig. 15. T.E. Brandrud 308-77 (O). Fig. 16. E. Bendiksen 49/87, holotypus (O). 


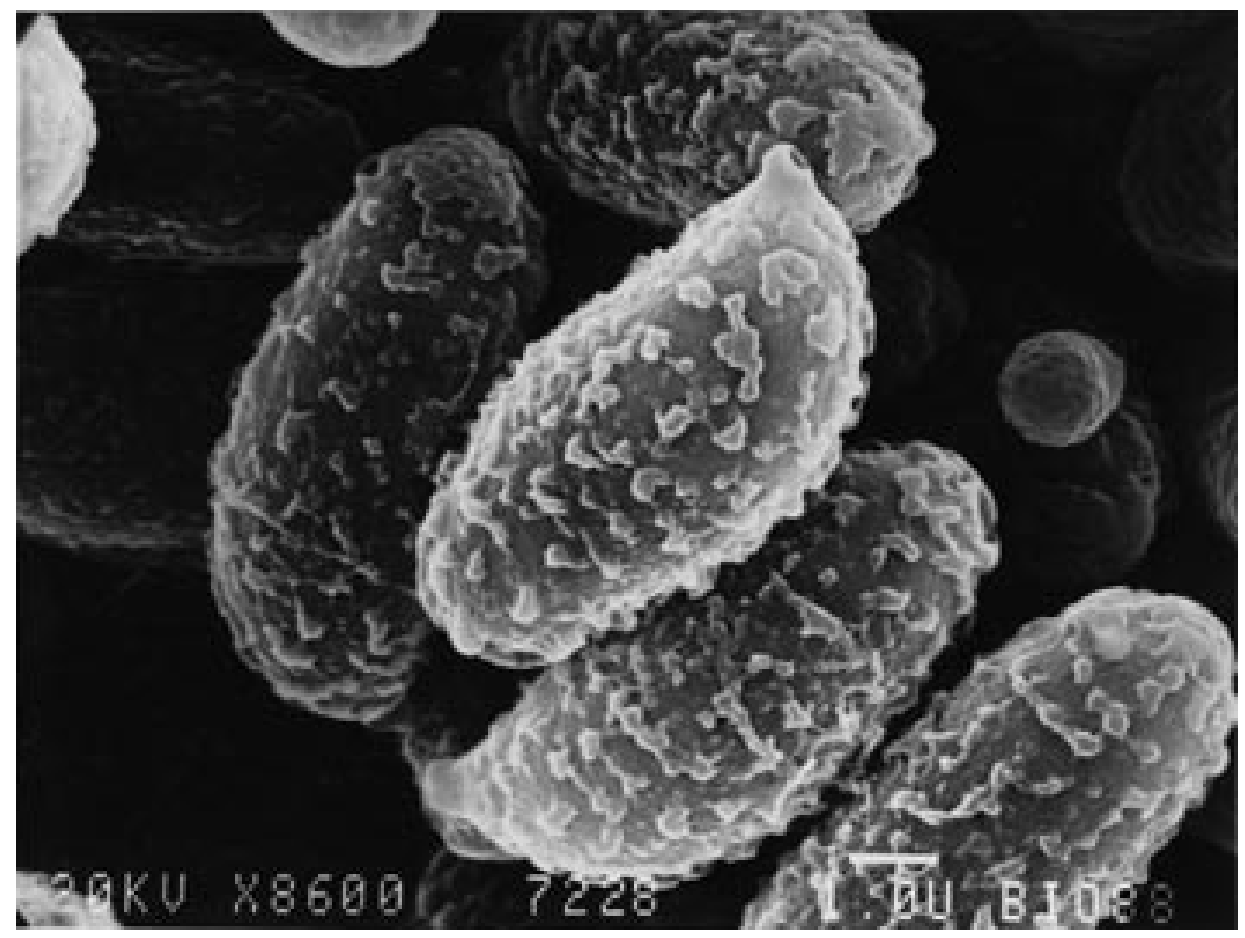

Fig. 17. Cortinarius aureovelatus. SEM spore picture. One of the listed samples from South Norway (details lost). Scale bar $=1 \mu \mathrm{m}$.

this forest type it is found in path borders, on exposed soil close to tree roots etc.

Note. The species is easily recognized by its rather vivid cap and gill colour and its golden yellow veil. The colour may remind somewhat of a Dermocybe, but the fruitbody has a typical Telamonia habit. At the same time it may at first sight be associated with $C$. saniosus, but with a much stouter habit. In sandy pine forest we also find $C$. odhinnii Melot, a Telamonia of the same size with strikingly vivid cap and narrow spores. However this species differs by its even stronger reddish component in the red-brown cap, white veil and penetrating smell (like in C. parvannulatus). The spores are also somewhat longer and $C$ odhinii usually comes later in season.

The original macroscopical description of C. majalis Vel. (Velenovský 1922: 447) might fit rather well with this species, a vernal coniferous species not uncommon in Bohemia in earlier days, according to M. Svrček (pers. comm.). However, investigation of the exsiccate of Velenovský (PRM) collected under this name revealed that the spores are broader and more ellipsoid than in our species. According to studies by Charvát (1958) C. majalis is a synonym to C. isabellinus Batsch ex Fr. (the species we now name C. colymbadinus Fr.).

In Brandrud (1979) C. aureovelatus was called C. laetus, and in Høiland (1980) the species was included in his description of a very variable "C. saniosus", recognized by spore morphology and ecology (his groups $\mathrm{C}$ and D). C. aureovelatus might also be hidden under the name $C$. saniosus in older literature, sometimes reported from coniferous forest. Information about associated tree species is, however, normally questionable, because many authors often seem to report no other than dominating tree species. 
Specimens examined (collections marked with * are DNA examined; "CFP" refers to the collection of Cortinarius Flora Photographica project. Collector initials HL refer to Håkan Lindström, EB to Egil Bendiksen, EKB to Egil and Katriina Bendiksen, KM to Katriina Metsänheimo (later Bendiksen) and KH to Klaus Høiland. HL-collections are in HL private herbarium except those marked UPS): Sweden: Medelpad, Sättna, Lövsätt, HL90.055; Ångermanland, Viksjö, Villola, Pinus, CFP929, (UPS)*; D:o, Säbro, Furuhult, CFP416 (UPS); D:o, Graninge, Viksmon, Pinus, CFP457 (UPS); Jämtland, Undersåker, Välliste, Picea, Betula CFP101 (UPS); D:o, Undersåker, Ottfjället, Picea, HL99.002; D:o, Frostviken, Jormvattnet, Picea, HL90.136; D:o, Ragunda Kullstabodarna, Picea, HL90.241; D:o, Hällesjö, Ånäset, HL90.239. Norway: Oppland, Lunner, Søndre Oppdalen CFP596 (UPS); D:o, eutrophic Picea-forest, EB 20.08.78 (O); D:o, eutrophic Picea-forest, EB 14.08.78 (O)*; D:o, eutrophic Picea-forest, EB 143/79 (O); D:o, oligotrophic Picea-forest, naked soil, near rotten stump, EB 27.07.02 (O)*; D:o, oligotrophic Picea-forest, by old stump, EB 09.08.01 (O); D:o, Rinilhaugen, oligotrophic Picea-forest, path, EB 13.08.05 (O); Oslo, Nordmarka, open young Picea-forest, KH et al.16.08.79 (O 123911, as cf. saniosus); D:o, gravelly roadside, open forest, Betula verrucosa, Pinus, Salix caprea, KH 26.08.79 (O 123897, as saniosus); D:o, gravelly roadside near open forest, Picea, Betula, KH 23.09.84 (O 123900, as saniosus); Telemark, Fyresdal, path in oligotrophic Pinus-forest, 630 m, EB 18.08.87 (49/87), holotypus (O)*; Aust-Agder, Gjerstad, moist oligotrophic Picea-Betula forest, by root, EB 01.09.94 (O). Finland: PH, Saarijärvi, Pyhä-Häkki, old Pinus-dominated forest, EB, KM 21.08.86 (O); EnL, Enontekiö, Kuttanen, margin of lichen-dominated Pinus-forest, roadside, EB, KM 08.08.85 (OULU); EnL, Enontekiö, Kilpisjärvi, subalpine, submesic Betula-forest, study plot 13, KM 20.08.84 (OULU); D:o, study plot 14, KM 20.08.84 (OULU).

\section{ACKNOWLEDGEMENTS}

The curator of the Royal Botanical Gardens herbarium at Edinburgh and Professor Denise Dailly (earlier Lamoure), Lyon, are greatly acknowledged for the permission to make DNA extraction and sequencing of the type specimens of $C$. aureomarginatus and C. chrysomallus, respectively; Andy F. S. Taylor, Department of Forest Mycology and Pathology, SLU, Uppsala for help with the English; Esteri Ohenoja, University of Oulu, for loan of collections of C. aureovelatus; the curator at Institute of Microbiology, University of Innsbruck for loan of collections by M. Moser; the curator of the National Museum of Praha for loan of collections of C. majalis Vel.; M. Svrček, National Museum of Praha, and Isabella Børja, Norwegian Forest and Landscape Institute, Ås, for useful information and translation of original Czech description of $C$. majalis, respectively; Roy Watling, University of Edinburgh, for practical assistance concerning type material; Tor Erik Brandrud for use of photo; Kurt Hjortstam, Alingsås, and Leif Ryvarden, University of Oslo, for assistance with the Latin diagnosis of $C$. aureovelatus, and Lars Erikstad, Norwegian Institute for Nature Research for technical support. Valuable comments from referees and editors and financial support from ArtDatabanken to EL is also gratefully acknowledged.

\section{REFERENCES}

Arnolds, E. \& Kuyper, T.W. 1995. Some rare and interesting Cortinarius species associated with Salix repens. - Sydowia 10: 5-27.

Bendiksen, E., Brandrud, T.E., Bendiksen, K. \& Lindström, H. 1993. A study of the Cortinarius helobius-complex, with special emphasis on arctic-alpine material. - Biblthca mycol. 150: 3-15.

Borgen, T. 1998. Four interesting taxa of Cortinarius (Basidiomycetes, Agaricales), subgenus Telamonia (Fr.) J.G. Trog. in Greenland. - Agarica 15: 179-188.

Brandrud, T.E. 1979. Noen slørsopper av underslekten Telamonia nye for Norge. - Blyttia 37: 149154.

Cailleux, A. 1981. Code des couleurs des sols. - Boubée, Paris. 
Chambers, S.M., Sawyer, N.A. \& Cairney, J.W.G. 1999. Molecular identification of co-occurring Cortinarius and Dermocybe species from southeastern Australian sclerophyll forest. - Mycorrhiza 9: 85-90.

Charvát, I. 1958. Vodohlav isabelový - Hydrocybe isabellina (Batsch ex Fr.) Rick. - Ceská Mycol. 12: $12-14$.

Fries, E. M. 1821. Systema mycologicum 1. Lundae.

Fries, E.M. 1838. Epicrisis systematis mycologici, seu synopsis Hymenomycetum. Upsaliae.

Gardes, M. \& Bruns, T.D. 1993. ITS primers with enhanced specificity for basidiomycetes - application to the identification of mycorrhizae and rusts. - Molec. Ecol. 2: 113-118.

Garnier, G. 1992. Bibliographie des Cortinaires. P-Z. - Fed. Mycol. Dauphine-Savoie, Toulouse

Høiland, K. 1975. De obligate storsoppene på sanddyner i Norge, med særlig vekt på forekomstene på Lista, Vest-Agder. - Blyttia 33: 127-140.

Høiland, K. 1980. Cortinarius subgenus Leprocybe in Norway. - Norw. J. Bot. 27: 101-126.

Hopple, J.S. Jr. \& Vilgalys, R. 1999. Phylogenetic relationships in the mushroom genus Coprinus and dark-spored allies based on sequence data from the nuclear gene coding for the large ribosomal subunit RNA: divergent domains, outgroups, and monophyly. - Molec. Phyl. Evol. 13: 1-19.

Kõljalg, U., Larsson, K-H., Abarenkov, K., Nilsson, R.H., Alexander, I.J., Eberhardt, U., Erland, S., Høiland, K., Kjøller, R., Larsson, E., Pennanen, T., Sen, R., Taylor, A.F.S., Tedorsoo, U., Vrålstad, T. \& Ursing, B.M. 2005. UNITE: a database providing web-based methods for the molecular identification of ectomycorrhizal fungi. - New Phytol. 166: 1063-1068.

Kornerup, A. \& Wanscher, J.H. 1978. Methuen handbook of colour, ed. 3. - Eyre Methuen, London.

Kühner, R. \& Romagnesi, H. 1953. Flore analytique des champignons superieurs. - Masson et Cie, Paris.

Kytövuori, I., Niskanen, T., Liimatainen, K. \& Lindström, H. 2005. Cortinarius sordidemaculatus and two new related species, C. neofurvolaesus and C. anisatus in Fennoscandia (Basidiomycota, Agaricales). - Karstenia 45: 33-50.

Lamoure, D. 1977 Agaricales de la zone alpine. Genre Cortinarius Fr. sous-genre Telamonia (Fr.) Loud. Première partie. - Trav. sci. Parc natl Vanoise 9: 77-101.

Lange, J.E. 1938. Flora Agaricina Danica, vol. 3. - The Society for the Advancement of Mycology in Denmark and The Danish Botanical Society, Copenhagen.

Larsson, E \& Hallenberg, N. 2001. Species delimitation in the Gloeocystidiellum porosum - clavuligerum complex inferred from compatibility studies and nuclear rDNA sequence data. - Mycologia 93: 907-914.

Larsson, K.-H. \& Larsson, E. 1998. A molecular perspective on Ceraceomyces sublaevis. - Folia crypt. eston. 33: 71-76.

Lundell, S \& Nannfeldt, J.A. 1979. Fungi exsiccati suecici, praesertim upsalienses. - Published by the authors, Uppsala.

Melot, J. 1995. Le genre Cortinarius en Islande. II. - Acta bot. isl. 12: 69-94.

Moser, M. 1983. Basidiomyceten 2. Teil. Die Röhrlinge und Blätterpilze (Polyporales, Boletales, Agaricales, Russulales). 5. Auflage. - In: Gams, H. (ed.), Kleine Kryptogamenflora, Band 2/b 2. Fischer, Stuttgart, pp. 1-538.

Moser, M., 1993. Studies on North American Cortinarii III. The Cortinarius flora of dwarf and shrubby Salix associations in the alpine zone of the Windriver Montains, Wyoming; USA. - Sydowia 45: 275-306.

Moser, M. \& McKnight, K. 1987. Fungi (Agaricales, Russulales) from the alpine zone of the Yellowstone National Park and the Beartooth mountains with special emphasis on Cortinarius. - In: Laursen, G.A. Ammirati, J. F. \& Readhead, S.A. (eds), Artic and alpine mycology II. 
- Plenum Press, New York, pp. 299-317.

Moser, M. \& Peintner, U. 2002. The species complex Cortinarius scaurus - C. herpeticus based on morphological and molecular data. - Micol. Veg. medit., 17: 3-17.

Orton, P.D. 1984. Notes on British agarics: VIII. - Notes r. bot. Gdn Edinb. 41: 565-624.

Peintner, U., Horak, E., Moser, M.M. \& Vilgalys, R. 2002. Phylogeny of Rozites, Cuphocybe and Rapacea inferred from ITS and LSU rDNA squences. - Mycologia 94: 620-629.

Sarnari, M. 1998. Monografia illustrata del genere Russula in Europa. Tomo primo. - Assoc. Micol. Bres. Fondazione, Centro Studi Micologici, Trento/Vicenza.

Seidl, M. 2000. Phylogenetic relationships within Cortinarius subgenus Myxacium, sections Defibulati and Myxacium. - Mycologia 92: 1091-1102.

Swofford, D.L. 2003. PAUP*. Phylogenetic Analysis Using Parsimony (* and Other Methods). Version 4. - Sinauer, Sunderland, MA.

Taylor, J.W., Jacobson, D.J., Kroken, S., Kasuga, T., Geiser, D.M., Hibbett, D.S. \& Fisher, M.C. 2000. Phylogenetic species recognition and species concepts in fungi. - Fungal Genet. Biol. 31: 21-32.

Velenovský, J. 1922. České Houby, vol. II. - České botanické společnosti, Praha.

Watling, R. 1992. Macrofungi associated with British willows. - Proc. R. Soc. Edinb. 98B: 135147.

White, T.J., Bruns, T., Lee, S. \& Taylor, J.W.1990. Amplification and direct sequencing of fungal ribosomal RNA genes for phylogenetics. - In: Innis, M.A, Gelfand, D.H., Sininsky, J.J. \& White, T.J. (eds), PCR Protocols: a guide to methods and applications. - Academic Press, New York, pp. 315-322. 